\title{
BÌNH DƯƠNG TRONG QUÁ TRÌNH HộI NHẬP KINH TẾ QUỐC TẾ CỦA VIỆT NAM TỪ NĂM 1986 ĐẾN NAY
}

\author{
NCS. Huỳnh Tâm Sáng
}

Trường Đại học Thủ Dầu Một

\section{Việt Nam trong quá trình hội nhập kinh tế quốc tế - Chủ trương và thành tựu}

Về mặt ngữ nghĩa, "hội nhập" có nguồn gốc tiếng Anh là "integrate"1 (liên kết) với ý nghĩa là hành động hoặc quá trình gắn kết các thành phần, bộ phận riêng rẽ lại với nhau thành một chỉnh thể (đồng nhất, hợp nhất) hay là việc kết hợp các thành tố khác nhau lại. Từ "hội nhập" đã được nêu ra lần đầu tiên trong Văn kiện Đại hội VIII của Đảng (1996), cụ thể là "xây dựng một nền kinh tế mở, hội nhập với khu vực và thế giới, hướng mạnh về xuất khẩu, đồng thời thay thế nhập khẩu bằng những sản phẩm trong nước sản xuất có hiệu quả”2.Với ý nghĩa đó, sau khi Chiến tranh Lạnh kết thúc, quá trình hội nhập quốc tế của Việt Nam đã có những bước phát triển vượt bậc với mức độ hội nhập ngày càng sâu rộng trên nhiều lĩnh vực, ở nhiều cấp độ khác nhau từ song phương, tiểu vùng, liên khu vực đến toàn cầu và ngày càng thu hút nhiều chủ thể quan hệ quốc tế tham gia từ các cơ quan Nhà nước đến các tổ chức phi chính phủ, công ty xuyên quốc gia, cá nhân,... ${ }^{3}$ Trong tiến trình hội nhập quốc tế thì hội nhập kinh tế quốc tế giữ vai trò hết sức quan trọng: là tiền đề và sức bật cho hội nhập ở các lĩnh vực khác.

Về cơ bản, "hội nhập kinh tế quốc tế"(international economic integration) có thể được hiểu là "quá trình gắn kết mang tính thể chế giữa các nền kinh tế lại với nhau"với việc sử dụng các tiêu chuẩn, nguyên tắc, chuẩn mực, tập quánchung (luật chơi chung) để tạo nên tính liên kết giữa các quốc gia. Các thị trường chung siêu quốc gia sẽ tạo điều kiện thuận lợi cho các nhân tố kinh tế giữa các nước di chuyển tự do. Đồng thời, hội nhập kinh tế quốc tế cũng sẽ tạo cơ sở vững chắc để thúc đẩy hội nhập chính trịi .

Với một ý nghĩa nhất định, hội nhập kinh tế quốc tế nằm trong khái niệm hội nhập nói chung là "tiến trình nhất thể hoá nền kinh tế thế giới, tức là xoá bỏ những khác biệt và sự

\footnotetext{
1 Từ điển Cambridge Advanced Learner's Dictionary ( $3^{r d}$ Edition) định nghĩa từ "integrate" như sau: (i) to mix with and join society or a group of people, often changing to suit their way of life, habits and customs; (ii) to combine two or more things in order to become more effective.

2 Đảng Cộng sản Việt Nam (2008), Văn kiện Đại hội Đảng thời kỳ đổi mói và hội nhập, Nxb. Chính trị Quốc gia, Hà Nội, tr. 342.

${ }^{3}$ Huỳnh Văn Sáng - Lục Minh Tuấn, "Phát triển du lịch Côn Đảo trong tiến trình hội nhập quốc tế của Việt Nam hiện nay", tr. 294 trong Trần Nam Tiến - Phạm Ngọc Trâm (chủ biên) (2014), Nhận diện và phát huy các giá trị tài nguyên biển đảo phục vụ phát triển bền vũng vùng Nam Bộ, Nxb. Đại học quốc gia thành phố Hồ Chí Minh. ${ }^{4}$ Balassa, B. (1967), "Trade Creation and Trade Diversion in the European Common Market", The Economic Journal, Vol. 77, No. 305 (Mar., 1967), pp. 1-21, Wiley, NJ, USA.
} 
phân biệt về kinh tế giữa các quốc gia và khu vực". Hay nói cách khác, "hội nhập kinh tế quốc tế tự nó là một quá trình "hóa thân" một cách chủ động của mỗi nước, mỗi khu vực vào trong các thực thể khu vực/ toàn cầu để một mặt, thể hiện được vị thế và tính tự cường quốc gia dân tộc và mặt khác, tham gia loại trù nhũng khác biệt để mình là một bộ phận hợp thành trong các chỉnh thể khu vực và toàn cầu đó"; hội nhập kinh tế quốc tế cũng "là quá trình liên kết kinh tế có mục tiêu, định hướng cụ thể gắn với phạm vi, cấp độ cũng như điều kiện cụ thể của mỗi nước ${ }^{\prime \prime}$.Như vậy, hội nhập kinh tế quốc tế thực chất là quá trình gắn kết nền kinh tế các quốc gia thông qua tự do hóa và mở cửa nền kinh tế trong sự tương tác tích cực với các nền kinh tế khu vực và thế giới. Những hình thức hội nhập kinh tế quốc tế cũng rất đa dạng: từ đơn phương, song phương, tiểu khu vực, khu vực, liên khu vực cho đến cấp độ toàn cầu.

Nhìn chung, tư duy hội nhập kinh tế quốc tế của Đảng và Nhà nước ta đã được hình thành khá sớm. Cụ thể, sau khi nước Việt Nam Dân chủ Cộng hòa được thành lập, trong Thư gửi Tổng Thư ký Liên Hợp Quốc (12/1946), Chủ tịch Hồ Chí Minhđã long trọng tuyên bố: “Đối với các nước dân chủ, nước Việt Nam sẵn sàng thực thi chính sách mở cửa và hợp tác trong mọi lĩnh vực:a) Nước Việt Nam dành sự tiếp nhận thuận lợi cho đầu tư của các nhà tư bản, nhà kỹ thuật nước ngoài trong tất cả các ngành kỹ nghệ của mình. b) Nước Việt Nam sẵn sàng mở rộng các cảng, sân bay và đường sá giao thông cho việc buôn bán và quá cảnh quốc tế. c) Nước Việt Nam chấp nhận tham gia mọi tổ chức kinh tế quốc tế dưới sự lãnh đạo của Liên Hợp Quốc"6. Rõ ràng, văn kiện ngoại giao đầu tiên của nước Việt Nam Dân chủ Cộng hoà đã nêu cao tư tưởng hội nhập kinh tế với khu vực và thế giới. Tư tưởng tiến bộ và cởi mở của Chủ tịch Hồ Chí Minh đã đặt ra cơ sở quan trọng cho đường lối hội nhập kinh tế quốc tế của Việt Nam sau này.

Bước vào thời kỳ “Đổi móx', với việc chuyển từ nền kinh tế chỉ huy bao cấp sang nền kinh tế hướng về thị trường, Đảng và Nhà nước đã bắt đầu thiết lập lại một tư duy kinh tế mới với các chương trình cải cách mạnh mẽ. Cuộc cách mạng hướng đến một thị trường tự do và cởi mở đòi hỏi vấn đề mở rộng quan hệ kinh tế với nước ngoài phải được thể chế hóa. Luật Đầu tư nước ngoài đã được Quốc hội nước Cộng hòa xã hội chủ nghĩa Việt Nam khóa VIII, kỳ họp thứ 2 thông qua ngày 29-12-1987 đã từng được xem là "một trong những luật cởi mở nhất châu Á và vùng ven Thái Bình Dương". Bộ Luật này khuyến khích đầu tư nước ngoài cùng với nó là chuyển nhượng công nghệ. Có bốn hình thức kinh doanh mở ra cho đầu tư nước ngoài: (i) hợp đồng hợp tác kinh doanh; (ii) công ty 100\% vốn nước ngoài; (iii) liên doanh; (iv) xây dựng - điều hành - chuyển giao (BOT) ${ }^{7}$. Luật Đầu tư và các nghị định áp dụng đã cho thấy tiếng nói quyết tâm và sẵn sàng “đổi mới"của Đảng và Nhà nước từ "tư duy"cho đến "chính sách" kinh tế với việc nêu cao tinh thần mà Hồ Chủ tịch từng khẳng

\footnotetext{
5 Nguyễn Xuân Thắng, Chương trình khoa học và công nghệ trọng điểm cấp Nhà nước, Đề tài: Quan hệ giữa độc lập, tự chủ và hội nhập kinh tế quốc tế trong bối cảnh mói của Việt Nam, Mã số: KX.04.12/06-10, Hà Nội, 2010, tr. 40-42.

${ }^{6}$ Hồ Chí Minh (2002), Toàn tập, Nxb. Chính trị Quốc gia, Hà Nội, Tập 4, tr. 470.

${ }^{7}$ Nguyễn Xuân Oánh (2001), Đổi mới - Vài nét lớn của một chính sách kinh tế Việt Nam, Nxb. Thành phố Hồ Chí Minh, tr. 47-57.
} 
định: "Nước Việt Nam là một, dân tộc Việt Nam là một".

Đại hội VI của Đảng Cộng sản Việt Nam (1986) đã cụ thể hóa một tầm nhìn chiến lược về tư duy và thực tiễn hội nhập kinh tế quốc tế.Bước vào thời kỳ Đổi mới, Đảng ta đã chủ trương mở rộng quan hệ kinh tế với các nước thế giới thứ ba, các nước công nghiệp phát triển, các tổ chức quốc tế và tư nhân nước ngoài trên nguyên tắc bình đẳng, cùng có lợi ${ }^{8}$.Chính sách Đổi mới cũng góp phần mang lại một diện mạo mới mẻ cho đất nước như một bước đột phá về kinh tế theo dạng "big-bang" đầy ấn tượng. Thành tựu tăng trưởng kinh tế có thể thấy rõ qua tốc độ tăng trưởng GDP và GDP bình quân đầu người.

Tăng trưởng kinh tế và cải thiện đời sống9

\begin{tabular}{|l|l|l|l|l|l|}
\hline Năm & $\begin{array}{c}\text { GDP thực tế } \\
\text { Tỷ đồng }\end{array}$ & $\begin{array}{c}\text { GDP/người } \\
\text { USD }\end{array}$ & \multicolumn{1}{|c|}{ Năm } & $\begin{array}{c}\text { GDP thực tế } \\
\text { Tỷ đồng }\end{array}$ & \multicolumn{1}{|c|}{$\begin{array}{c}\text { GDP/người } \\
\text { USD }\end{array}$} \\
\hline 1986 & 109.189 & 202,36 & 1997 & 231.264 & 346,39 \\
\hline 1987 & 113.154 & 204,98 & 1998 & 244.596 & 361,40 \\
\hline 1988 & 119.960 & 210,86 & 1999 & 256.269 & 373,82 \\
\hline 1989 & 125.571 & 220,69 & 2000 & 273.670 & 394,29 \\
\hline 1990 & 131.968 & 227,07 & 2001 & 292.526 & 416,53 \\
\hline 1991 & 139.634 & 235,85 & 2002 & 313.119 & 441,01 \\
\hline 1992 & 151.782 & 251,48 & 2003 & 335.784 & 468,27 \\
\hline 1993 & 164.043 & 266,81 & 2004 & 335.784 & 498,95 \\
\hline 1994 & 178.534 & 285,21 & 2005 & 335.784 & 635,00 \\
\hline 1995 & 195.567 & 301,96 & 2006 & 335.784 & 715,00 \\
\hline 1996 & 213.833 & 325,02 & 2007 & 335.784 & 835,00 \\
\hline & & & 2008 & 335.784 & $1,030,00$ \\
\hline
\end{tabular}

Kế thừa và phát huy sáng tạo phương châm đổi mới tư duy và mở rộng các quan hệ kinh tế củaĐại hội VI, Đại hội VII của Đảng Cộng sản Việt Nam (1991) cũng mở ra bước đột phá cho hội nhập kinh tế quốc tế với nguyên tắc căn bản là: "mở rộng, đa dạng hoá và đa phương hoá quan hệ kinh tế đối ngoại trên nguyên tắc giữ vững độc lập chủ quyền, bình đẳng, cùng

\footnotetext{
8 Đảng Cộng sản Việt Nam (1987), Văn kiện Đại hội đại biểu toàn quốc lần thú VI, Nxb. Sự thật, Hà Nội, tr. 81.

${ }^{9}$ Phạm Minh Chính - Vương Quân Hoàng (2009), Kinh tế Việt Nam: Thăng trầm và đột phá, Nxb. Tri thức, Hà Nội, tr. 99.
} 
có lợi”10. Đại hội Đảng lần thứ VIII (1996) cũng nêu cao phương châm tích cực và chủ động thâm nhập và mở rộng thị trường quốc tế, tiến hành từng bước vững chắc để gia nhập APEC, WTO ${ }^{11 .}$

Bước vào thế kỷ XXI, tuy vẫn còn những cạnh tranh và xung đột nhưng xu thế hòa bình và hợp tác đã trở thành xu thế của thời đại. Trong các vấn đề hợp tác thì kinh tế là lĩnh vực hợp tác hàng đầu với vai trò là "nhân tố quyết định sức mạnh tổng hợp của mỗi quốc gia và vị thế quốc gia đó trên trường quốc tế"12. Trong chiến lược 10 năm phát triển kinh tế - xã hội (2001 - 2010), vấn đề hội nhập kinh tế quốc tế cũng được quan tâm rõ rệt.Nghị quyết số 07/NQ-TW về "Hội nhập kinh tế quốc tế"của Bộ chính trị vào ngày 27-11-2001 nhấn mạnh: "Chủ động hội nhập kinh tế quốc tế và khu vực theo tinh thần phát huy tối đa nội lực, nâng cao hiệu quả hợp tác quốc tế, bảo đảm độc lập tự chủ và định hướng xã hội chủ nghĩa, bảo vệ lợi ích dân tộc; an ninh quốc gia, giữ gìn bản sắc văn hóa dân tộc, bảo vệ môi trường..."13.Cũng trong Đại hội Đảng toàn quốc lần thứ IX, lần đầu tiên xuất hiện cụm từ "chủ động hội nhập kinh tế quốc tể". Từ đây, hội nhập kinh tế quốc tế đã trở thành đòi hỏi cấp thiết với sự tham gia tích cực của nhiều thành phần trong xã hội.

Đại hội Đảng toàn quốc lần thứ X (2006) tiếp tục đề ra chủ trương "Thực hiện nhất quán đường lối đối ngoại độc lập tự chủ, hòa bình, hợp tác và phát triển; chính sách đối ngoại rộng mở, đa phương hóa, đa dạng hóa các quan hệ quốc tế. Chủ động và tích cực hội nhập kinh tế quốc tế, đồng thời mở rộng hợp tác quốc tế trên các lĩnh vực khác"14.Điểm mới và đặc biệt quan trọng về chủ trương "hội nhập kinh tế quốc tế" của Đảng trong Đại hội X là bên cạnh "chủ động" thì Việt Nam cần "tích cựchội nhập kinh tế quốc tế. Yêu cầu mới này đặt ra những bước đi mạnh mẽ hơn để Việt Nam phát huy tối đa khả năng và ý chí hội nhập kinh tế quốc tế.

Nghị quyết Đại hội XI (2011) tiếp tục kế thừa và phát huy chủ trương hội nhập kinh tế quốc tế của đại hội X: "Thực hiện nhất quán đường lối đối ngoại độc lập, tự chủ, hòa bình, hợp tác và phát triển đa phương hóa, đa dạng hóa quan hệ, chủ động và tích cực hội nhập quốc tế"15. Như vậy có thể nhận thấy rằng, hòa cùng tư duy hội nhập quốc tế thì chủ trương hội nhập kinh tế quốc tế là một xu thế hoàn toàn phù hợp với sự vận động của tình hình khu vực, thế giới và thực tiễn phát triển của Việt Nam. Từ đây, hội nhập kinh tế quốc tế là một

\footnotetext{
10Đảng Cộng sản Việt Nam (1991), Văn kiện Đại hội đại biểu toàn quốc lần thứ VII, Nxb. Chính trị Quốc gia, Hà Nội, tr. 119.

11 Đảng Cộng sản Việt Nam (2005), Văn kiện Đại hội Đảng thời kỳ đổi mói (Đại hội VI, VII, VIII, IX), Nxb. Chính trị Quốc gia, Hà Nội, tr. 664.

12 Nguyễn Khắc Huỳnh (2011), Ngoại giao Việt Nam - Góc nhìn và suy ngấm, Nxb. Chính trị quốc gia, Hà Nội, tr. 276.

13 Đảng Cộng sản Việt Nam (2004), Các Nghị quyết của Trung ương Đảng (2001 - 2004), Nxb. Chính trị Quốc gia, Hà Nội, tr. 256.

14 Đảng Cộng sản Việt Nam (2006), Văn kiện Đại hội đại biểu toàn quốc lần thứ X, Nxb. Chính trị Quốc gia, Hà Nội, tr. 112.

15 Đảng Cộng sản Việt Nam (2011), Văn kiện Đại hội đại biểu toàn quốc lần thứ XI, Nxb. Chính trị Quốc gia, Hà Nội, tr. 236.
} 
tiến trình mang tính hai mặt: một mặt thể hiện được lợi thế và tính tự cường quốc gia - dân tộc, mặt khác góp phần loại trừ dần các khác biệt để Việt Nam trở thành một bộ phận không thể tách rời trong chỉnh thể thị trường khu vực và thế giới ${ }^{16}$.

Từ góc độ thực tiễn, quá trình hội nhập kinh tế quốc tế ở Việt Nam thực chất được bắt đầu từ trước Đổi mới với sự kiện Việt Nam gia nhập Hội đồng Tương trợ Kinh tế (SEV) năm 1978.Những sự kiện tiếp theo như việc Việt Nam bình thường hóa quan hệ với Quỹ Tiền tệ quốc tế (IMF), Ngân hàng thế giới (WB), Ngân hàng Phát triển châu Á (ADB) vào tháng 10/1993 cũng đánh dấu nhận thức ngày càng sâu sắc về hội nhập kinh tế quốc tếtrong tư duy đối ngoại của Việt Nam¹7. Sau khi gia nhập Hiệp hội các Quốc gia Đông Nam Á (ASEAN) năm 1995, Việt Nam cũng tham gia Khu vực thương mại tự do ASEAN (AFTA) từ năm 1996, ký Hiệp định khung với EU (1995); tham gia Diễn đàn Hợp tác Á - Âu (ASEM) năm 1996 với tư cách là một trong 25 thành viên sáng lập, gia nhập Diễn đàn Hợp tác Kinh tế châu Á Thái Bình Dương (APEC) năm 1998.Hiệp định Thương mại Việt Nam - Hoa Kỳ được ký kết (13/7/2000), với tư cách là hiệp định song phương đầu tiên về hợp tác thương mại của Việt Nam dựa trên các nguyên tắc tự do hóa thương mại của WTO, cũng là thành công của Việt Nam trên đường hội nhập kinh tế quốc tế. Có thể nói, những bước đi đầy tính khích lệ này đã trở thành "lực đẩy" để giúp Việt Nam hội nhập kinh tế quốc tế ngày càng sâu rộng hơn.

Trên bình diện khu vực và liên khu vực, Việt Nam đã lần lượt tham gia vào các cơ chế liên kết và hợp tác kinh tế khu vực của ASEAN. Đặc biệt, Việt Nam cũng phối hợp tích cực cùng các quốc gia thành viên để triển khai những mục tiêu và chiến lược xây dựng Cộng đồng ASEAN 2015 trên cả ba trụ cột là Cộng đồng Chính trị - An ninh ASEAN (APSC), Cộng đồng Kinh tế ASEAN (AEC) và Cộng đồng Văn hóa - Xã hội (ASCC). Bên cạnh đó, Việt Nam cũng tham gia vào các tiến trình liên kết kinh tế giữa ASEAN với các đối tác bên ngoài, đặc biệt là Khu vực Thương mại tự do ASEAN - Trung Quốc, ASEAN - Nhật Bản, ASEAN - Hàn Quốc, ASEAN - Ấn Độ, ASEAN - Australia - New Zealand; phối hợp nghiên cứu và thúc đẩy khả năng đàm phán Hiệp định thương mại tự do với EU, Mỹ; Hiệp định thương mại tự do Đông Á/ Cộng đồng Đông Á; tích cực đàm phán để tham gia Hiệp định đối tác kinh tế xuyên Thái Bình Dương (TPP),... ${ }^{18}$

Trên bình diện toàn cầu, sự kiện Việt Nam được chính thức kết nạp làm thành viên thứ 150 của Tổ chức thương mại thế giới (WTO) vào năm 2006 là một thành tựu vô cùng to lớn từ hoạt động hội nhập kinh tế quốc tế của Việt Nam và "mở ra một thời kỳ mới trong tiến trình

\footnotetext{
16Nguyễn Xuân Thắng, "Chủ động tích cực hội nhập kinh tế quốc tế - Động lực phát triển của Việt Nam trong giai đoạn mới”, Tạp chí Nhũ̃ng vấn đề Kinh tế và Chính trị thế giới, Số 9 (113), 2005, tr. 56-66.

17 Đặng Đình Quý, "Bàn thêm về khái niệm và nội hàm "hội nhập quốc tế" của Việt Nam trong giai đoạn mới", Tạp chí Nghiên cứu quốc tế, Số 4 (91), 2012, tr. 23-24.

18 Phạm Quốc Trụ, "Nhìn lại quá trình hội nhập kinh tế quốc tế của Việt Nam những năm qua và một số khuyến nghị”, tr. 101-105 trong Phạm Bình Minh (chủ biên) (2011), Định hướng chiến lược đối ngoại Việt Nam đến 2020, Nxb. Chính trị Quốc gia, Hà Nội.
} 
hội nhập - thời kỳ tham gia bình đẳng trong sự hợp tác và cạnh tranh"19. Việc gia nhập và thực hiện các cam kết của Việt Nam góp phần thúc đẩy gia tăng chiều sâu trong quan hệ giữa Việt Nam và các nước đối tác, thể hiện ở cả ba tiêu chí quan trọng là "mức độ đan xen lợi ích, đặc biệt là lợi î́ch kinh tế; số lượng và hiệu quả của các cơ chế hợp tác giữa hai bên; mức độ tin cậy và hiểu biết lẫn nhau"20. Nỗ lực của Việt Nam đã phản ánh đúng đắn tính thiết thực của định hướng đối ngoại tại Đại hội X Đảng Cộng sản Việt Nam (2006) về "chủ động và tích cực hội nhập kinh tế quốc tế, đồng thời mở rộng hợp tác quốc tế trên các lĩnh vực khác"21.Với việc gia nhập vào WTO, Việt Nam đã hội nhập đầy đủ vào nền kinh tế thế giới; cùng với chiến lược hội nhập kinh tế quốc tế thì bước đột phá nàycũng đã mở ra cho Việt Nam những cơ hội mới để hội nhập vào các lĩnh vực khác.

Trong thập niên đầu tiên của thế kỷ XXI, hội nhập kinh tế quốc tế của Việt Nam đã mang lại nhiều thành tựu nổi bật, góp phần làm gia tăng sức mạnh tổng hợp của quốc gia: (i) Tư duy phát triển của kinh tế Việt Nam có những bước chuyển quan trọng ở cả khu vực nhà nước và tư nhân; (ii) Thể chế kinh tế thị trường theo định hướng xã hội chủ nghĩa ngày càng hoàn chỉnh, hệ thống pháp lý ngày một hài hòa với các quy định, tiêu chuẩn quốc tế; (iii) Tranh thủ được nguồn vốn đầu tư, viện trợ và kiều hối, đưa cơ cấu kinh tế chuyển dịch tích cực theo hướng gia tăng tỉ trọng công nghiệp, dịch vụ và sản phẩm có giá trị gia tăng cao; (iv) Vị thế và tiềm năng kinh tế quốc tế của nước ta được cải thiện và đánh giá cao ${ }^{22}$.

Gần 30 năm đổi mới và hội nhập, quá trình từng bước hội nhập kinh tế quốc tế của Việt Nam đã đạt được nhiều thành tựu có ý nghĩa to lớn cả về phương diện lý luận lẫn thực tiễn.Về phương diện lý luận, việc nêu cao chủ trương hội nhập kinh tế quốc tế đánh dấu bước chuyển biến trong tư duy đối ngoại của Đảng về sự gắn bó thiết thân giữa Việt Nam và thế giới như mối quan hệ tương hỗ, biện chứng. Việt Nam ngày càng chứng tỏ một sự thật quan trọng: Việt Nam đang trở thành một bộ phận tích cực trong tổng thể sự phát triển kinh tế của thế giới. Về phương diện thực tiễn,quá trình hội nhập kinh tế quốc tế của Việt Nam là sự khẳng định về khả năng và những cam kết trách nhiệm của Việt Nam trên con đường củng cố nội lực và tranh thủ các nguồn lực bên ngoài để phát triển đất nước.

Có thể nói, quá trình hội nhập kinh tế quốc tế của Việt Nam "vừa thích hợp với các yêu cầu đặt ra của toàn cầu hóa kinh tế, vừa phù hợp với các điều kiện kinh tế - xã hội đặc thù của Việt Nam. Từ mở cửa thị trường (ở giai đoạn đầu của đổi mới kể từ năm 1986) đến chủ động hội nhập kinh tế quốc tế (nửa đầu nhiệm kỳ Đại hội IX); từ đa dạng hóa các quan hệ kinh tế đối ngoại đến chủ động tích cực hội nhập kinh tế quốc tế (nửa cuối nhiệm kỳ Đại hội

\footnotetext{
19 Vũ Dương Ninh, "Việt Nam mở cửa và hội nhập nhìn từ kinh nghiệm thế kỷ XX”, Tạp chí Nghiên cứu lịch sử, Số 6, 2009, tr. 9.

20Đặng Đình Quý, "Nhìn lại 5 năm sau gia nhập WTO: Một số tác động về đối ngoại và bài học đối với Việt Nam", Tạp chí Nghiên cúu quốc tế, Số 1 (88), 2012, tr. 10.

${ }^{21}$ Đảng Cộng sản Việt Nam (2006), Văn kiện đại hội đại biểu toàn quốc lần thứ X, Nxb. Chính trị Quốc gia, Hà Nội, tr. 112.

22 Phạm Bình Minh, "Chủ động và tích cực hội nhập quốc tế theo tinh thần Nghị quyết Đại hội Đảng toàn quốc lần thứ XI”, Tạp chí Nghiên cúu quốc tế, Số 4 (91), 2012, tr. 13.
} 
IX), Việt Nam đã có sự đổi mới thực sự về tư duy hội nhập"23. Tư duy đúng đắn và mới mẻ đã giúp Việt Nam cải cách trong nước để chủ động hội nhập kinh tế quốc tế với sự phong phú và đa dạng từ cấp độ, hình thức cho đến nội dung hội nhập.

Nỗ lực của Việt Nam còn góp phần cho thấy tính đúng đắn của chính sách đối ngoại rộng mở, đa dạng hoá, đa phương hoá các mối quan hệ quốc tế.Trong quá trình hội nhập kinh tế quốc tế, sự tham gia tích cực của các "vùng trọng điểm”trong cả nước đã và đang góp phần to lớn tạo nên sức cạnh tranh cho nền kinh tế Việt Nam. Cũng chính sự năng động của các địa phương đã góp phần tăng tính hấp dẫn của Việt Nam như là điểm đến đầy tiềm năng cho hoạt động đầu tư trực tiếp nước ngoài và đầu tư gián tiếp. Với thế mạnh là một điểm đến đầy tiềm năng về phát triển kinh tế và tăng trưởng, tỉnh Bình Dương đang trở thành một trong những điển hình của quá trình hội nhập kinh tế quốc tế vùng, miền của Việt Nam.

\section{Bình Dương trong tiến trình hội nhập kinh tế quốc tế Việt Nam từ năm 1986 đến nay}

Trải qua thăng trầm của lịch sử, vùng đất Bình Dương đã có nhiều giai đoạn phân tách và hợp nhất các đơn vị hành chính. Từ sau ngày miền Nam hoàn toàn giải phóng (1975), căn cứ theo Quyết định ngày 2-7-1976 tại kỳ họp thứ nhất quốc hội khóa VI của Quốc hội nước Cộng hòa xã hội chủ nghĩa Việt Nam, tỉnh Sông Bé được thành lập trên cơ sở sáp nhập tỉnh Thủ Dầu Một và tỉnh Bình Phước. Kể từ ngày 1-1-1997, tỉnh Bình Dương được chính thức thành lập trên cơ sởlà một trong hai tỉnh được tách ra từ tỉnh Sông Bé (tỉnh còn lại là tỉnh Bình Phước) ${ }^{24}$.Với vị trí thuộc miền Đông Nam Bộ, Bình Dương nằm trong "vùng kinh tế trọng điểm phía Nam" và tiếp giáp với thành phố Hồ Chí Minh về mạn nam và tây nam, tỉnh Bình Phước về phía bắc, tỉnh Tây Ninh về phía tây, tỉnh Đồng Nai về phía tây vànối sườn phía nam của dãy Trường Sơn với các tỉnh đồng bằng sông Cửu Long.Vị trí chiến lược đặc biệt quan trọng này đã giúp Bình Dương trở thành một vùng đệm không thể thay thế nằm trên hành lang nối Sài Gòn với các tỉnh miền Đông, miền Trung và miền Tây Nam Bộ 25 .

Từ khi tách tỉnh, Bình Dương không sở hữu những điều kiện thuận lợi về cảng biển, sân bay, cửa khẩu;cơ sở hạ tầng không thật sự quy củ, nguồn lực lao động cũng chưa dồi dào,... Mặc dù vị trí địa lý nằm hoàn toàn trong đất liền(land-locked) nhưng Bình Dương có nhiều tiềm năng phát triển khi sở hữu điều kiện giao thông vận tải thuận lợi nối với các tuyến đường quốc gia quan trọng như quốc lộ 13, quốc lộ 14, quốc lộ 31, quốc lộ $1 \mathrm{~A}$, đường cao tốc thành phố Hồ Chí Minh, đường vành đai vùng thành phố Hồ Chí Minh...và là đầu mối ga đường sắt quốc gia tại An Bình- Sóng Thần, đường sắt Xuyên Á. Song song đó, tỉnh cũng gầnsân bay quốc tế Tân Sơn Nhất (thành phố Hồ Chí Minh), cảng Sài Gòn (thành phố Hồ Chí

\footnotetext{
${ }^{23}$ Nguyễn Xuân Thắng (chủ biên) (2007), Toàn cầu hóa kinh tế và hội nhập kinh tế quốc tế đối với tiến trình công nghiệp hóa, hiện đại hóa ở Việt Nam, Nxb. Khoa học xã hội, Hà Nội, tr. 144-148.

${ }^{24}$ Hồ Sơn Đài (chủ biên) (2010), Lịch sử Lực lượng Vũ trang Nhân dân tỉnh Bình Dương (1945 - 2005), Nxb. Tổng hợp thành phố Hồ Chí Minh, tr. 9.

${ }^{25}$ Hồ Sơn Đài (chủ biên) (2010), Lịch sử Lực lượng Vũ trang Nhân dân tỉnh Bình Dương (1945 - 2005), Sđd, tr. 639.
} 
Minh), cảng Cái Mép- Thị Vải (tỉnh Bà Rịa - Vũng Tàu). Những con đường huyết mạch giúp việc di chuyển từ Bình Dương đến thành phố Hồ Chí Minh và các vùng phụ cận được dễ dàng. Hệ thống hồ Dầu Tiếng(sông Sài Gòn), hồ Trị An (sông Đồng Nai), hồ Phước Hòa (giáp ranh giữa tỉnh Bình Dương và tỉnh Bình Phước) đảm bảo cung cấp nước, giữ gìn cân bằng hệ sinh thái vùng và tỉnh Bình Dương trong quá trình công nghiệp hóa, đô thị hóa ${ }^{26}$. Đồng thời,Bình Dương cũng có thể tận dụng được lợi thế cảng biển của thành phố Hồ Chí Minh như Sài Gòn, Cát Lái, Hiệp Phước,... Với những lợi thế trên, Bình Dương là điểm đến đầy tiềm năng cho những hoạt động đầu tư của các doanh nghiệp nước ngoài. Ưu thế này cũng góp phần thúc đẩy Bình Dương chủ động và tự tin phát huy tối đa năng lực trong quá trình hội nhập kinh tế quốc tế.

Song song đó, với vị trí tiếp giáp với thành phố Hồ Chí Minh - trung tâm kinh tế, tài chính, công nghiệp và khoa học - công nghệ của Nam Bộ, Bình Dương từ rất sớm đã có sự nhạy cảm với những diễn biến về kinh tế - chính trị ở Nam Bộ và mau chóng hòa vào xu thế hội nhập kinh tế của vùng. Vị trí chiến lược này còn giúp Bình Dương dễ dàng thu hút nguồn vốn, tiếp cận tiến bộ khoa học - công nghệ và thông tin kinh tế, thị trường.Ngoài ra, Bình Dương còn có thể thuận lợi trong khai thác hầu hết cơ sở hạ tầng sẵn có của thành phố Hồ Chí Minh và các loại hình dịch vụ hiện đại để phát triển công nghiệp27.Tận dụng ưu thế về mặt địa lý giúp Bình Dương dễ dàng bắt kịp với sự vận động từ công cuộc hội nhập kinh tế quốc tế phía nam nói riêng và cả nước nói chung.

Trong suốt 30 năm chiến tranh giải phóng dân tộc (1945 - 1975), Bình Dương tồn tại hai loại hình kinh tế - xã hội cơ bản là: loại hình kinh tế - xã hội thực dân thời chiến (ở vùng tạm chiếm) và loại hình kinh tế - xã hội kháng chiến (ở chiến khu, vùng giải phóng). Nhìn chung, kinh tế - xã hội Bình Dương trong thời kỳ này vô cùng rối ren và tồn tại nhiều bất cập. Trong giai đoạn 1975 - 1986, mặc dù đã có nhiều nỗ lực để vực dậy nền kinh tế nhưng tỉnh Sông Bé vẫn còn là tỉnh nghèo, kém phát triển.Với đường lối “đổi mói i" từ Đại hội Đảng Cộng sản Việt Nam lần VI (1986), nền kinh tế hàng hóa nhiều thành phần theo định hướng xã hội chủ nghĩa được xác lập đã trở thành động lực để Bình Dương tích cực đổi mới theo hướng chú trọng vào công nghiệp thay cho một nền kinh tế vốn lấy nông nghiệp là truyền thống. Đặc biệt, trong khi thành phố Hồ Chí Minh triển khai xây dựng các khu chế xuất (với dự án lớn và quy mô bình quân đầu tư cao) thì Bình Dương lại lựa chọn xây dựng khu công nghiệp (với dự án vừa và nhỏ, quy mô đầu tư nhỏ). Sự linh hoạt trong việc lựa chọn cách thức đầu tư đã giúp tổng sản lượng công nghiệp của tỉnh tăng nhanh, có năm tăng gần 100 lần²8. Tầm

\footnotetext{
${ }^{26}$ Huỳnh Văn Minh, "Bình Dương - Quá trình phát triển công nghiệp, đô thị và các bài học kinh nghiệm",Viện Quy hoạch phát triển đô thị Bình Dương, tại địa chỉ: http://vienquyhoachbinhduong.com/chi-tiet/63/binhduong-qua-trinh-phat-trien-cong-nghiep-do-thiva-cac-bai-hoc-kinh-nghiem.html, truy cập ngày 27/2/2014. 27“Tạo nền tảng để phát triển nhanh và bền vững”, tr. 143 trong Công ty Cổ phần Thông tin Đối ngoại (2008), Bình Dương hội nhập - Bài học thành công, Nxb. Chính trị Quốc gia, Hà Nội.

${ }^{28}$ Nguyễn Văn Hiệp (2013), Sự chuyển biến kinh tế - xã hội tỉnh Bình Dương 1945 - 2007, Nxb. Chính trị Quốc gia, Hà Nội, tr. 352-359.
} 
nhìn này đã chứng tỏ tính đúng đắn khi bốn năm sau Chính phủ mới có Nghị định 36/NĐCP về việc xây dựng và quản lý các khu công nghiệp (ngày 24-4-1997).

Các khu công nghiệp đã giúp thu hút đầu tư nước ngoài - một nguồn lực quan trọng để "tăng nhanh sản phẩm xuất khẩu, tiếp cận với thị trường quốc tế, đóng góp tích cực vào các hoạt động xã hội, đổi mới cơ chế quản lý, cải cách thủ tục hành chính, nâng cấp cơ sở hạ tầng, kích thích các ngành dịch vụ phát triển"29.Suy cho cùng, nguồn vốn FDI sẽ đóng góp to lớn vào việc thúc đẩy tiến trình công nghiệp hóa, hiện đại hóa của tỉnh. Với tầm nhìn liên kết vùng, Bình Dương đã sớm gắn kết sự phát triển địa phương với các tỉnh, thành trọng điểm phía Nam;đặc biệt là Đồng Nai, Bà Rịa - Vũng Tàu và thành phố Hồ Chí Minh để tạo thành tứ giác phát triển với một mạng lưới các khu công nghiệp, dịch vụ thương mại, tài chính,... để tạo động lực góp phần thúc đẩy quá trình hội nhập kinh tế quốc tế của cả khu vực phía $\mathrm{Nam}^{30}$.Nguồn thu FDI là nguồn vốn quan trọng thúc đẩy sự chuyển dịch cơ cấu kinh tế, hỗ trợ cho các doanh nghiệp phát triển theo hướng đa dạng hóa và chuyên môn hóa các ngành nghề và lĩnh vực hoạt động.

Đặc biệt, từ sau ngày miền Nam được hoàn toàn giải phóng (1975), trong quá trình từng bước chuyển sang nền kinh tế thị trường, Bình Dương đã dần khẳng định mình thông qua những nỗ lực "cải cách cơ chế, xác lập một mẫu hình mới về mối quan hệ chức năng Nhà nước - thị trường, áp dụng chính sách thu hút đầu tư phát triển một cách thông thoáng"31. Những nỗ lực này một mặt phản ánh xu thế chung về tính năng độngcủa các tỉnh trong vùng kinh tế trọng điểm phía Nam, mặt khác cũng cho thấy một Bình Dương đã và đang tích cực xây dựng hình ảnh của một địa phương mang dáng dấp trẻ, khỏe và giàu sức sống về tăng trưởng và phát triển.

Từ những năm 1990, Bình Dương đã đề xuất chủ trương "trải thảm đỏ, đón nhà đầu tu" để thu hút nguồn vốn và công nghệ nước ngoài giúp địa phương phát triển. Phát huy tối đa lợi thế là cửa ngõ vào thành phố Hồ Chí Minh, Bình Dương đã cụ thể hóa các chủ trương, đường lối, chính sách của Đảng, Nhà nước một cách linh hoạt, chủ động vào điều kiện cụ thể của địa phương. Từ đây, những chỉ thị và hướng dẫn đã gắn bó chặt chẽ với thực tiễn và phát huy vai trò định hướng rõ rệt.Ngay từ Đại hội Đảng bộ Tỉnh lần thứ VI (năm 1997), Bình Dương đã đưa ra chủ trương “Tạo môi trường, điều kiện thuận lợi, phát huy mạnh hơn nữa các lợi thế địa lý, nguồn lực, tiềm năng trong dân, các doanh nghiệp trong Tỉnh, thu hút mạnh các nguồn lực ngoài tỉnh và nước ngoài, tạo động lực phát triển; hình thành kinh tế mở, mở rộng các quan hệ với bên ngoài; phát huy tối đa các nguồn lực nước ngoài đầu tư

\footnotetext{
${ }^{29}$ Nguyễn Văn Hiệp (2013), Sự chuyển biến kinh tế - xã hội tỉnh Bình Dương 1945 - 2007, Sđd, tr. 238.

30 Huỳnh Đức Thiện, "Đặc điểm kinh tế - xã hội vùng Đông Nam Bộ trong quá trình hội nhập và phát triển đất nước”, tr. 541 trong Võ Văn Sen (chủ biên) (2013), Nam Bộ - Đất và Người (Tập IX), Nxb. Đại học Quốc gia thành phố Hồ Chí Minh.

31 "Vùng kinh tế trọng điểm phía Nam: động lực phát triển của nền kinh tế - Phần 1", Cục xúc tiến thương mại, 20/10/2011, tại địa chỉ: http://www.vietrade.gov.vn/vung-kinh-te-trong-diem-phia-nam/2433-vung-kinhte-trong-diem-phia-nam-dong-luc-phat-trien-cua-nen-kinh-te-phan-1.html, truy cập ngày 26/2/2012.
} 
phát triển công nghiệp"32. Chủ trương hội nhập kinh tế trên cơ sở tận dụng tối đa các điều kiện thuận lợi của địa phương được xem như "kim chỉ nam" để Bình Dương tiếp tục theo theo đuổi con đường phát triển vươn tầm ra bên ngoài.

Nếu như trong giai đoạn 1991 - 1995, thu hút FDI của Bình Dương không đáng kể với 382 triệu USD, chiếm 2,4\% tổng số vốn đầu tư nước ngoài của cả nước,chỉ hơn các tỉnh đồng bằng sông Cửu Long, nhưng vẫn xếp sau Đồng Nai, Bà Rịa - Vũng Tàu, Hà Nội, thành phốHồ Chí Minh thì đến giai đoạn 1996-2006, thu hút FDI tại Bình Dương tăng vọt lên 1,6 tỷ USD. Điều này đã cho thấy tính hiệu quả của chính sách "trải chiếu hoa, mời gọi nhà đầu tư" của tỉnh từ năm 1995. Sang năm 2007, Bình Dương thu hút 1.571 dự án đầu tư nước ngoài với vốn đầu tư đã tăng gần gấp đôi so với năm 2006 (2,9 tỷ USD). Thành tựu này là do từ năm 2006, Bình Dương đã "thay đổi chính sách kêu gọi đầu tư theo định hướng phát triển bền vững, tập trung kêu gọi đầu tư vào các khu công nghiệp, cụm công nghiệp đã được quy hoạch, không thu hút các dự án có nguy cơ ô nhiễm cao, thâm dụng lao động... Do đó, nguồn vốn FDI ngày càng tăng lên về lượng và từng bước đi vào chất và phát triển theo chiều sâu, góp phần quan trọng vào tăng trưởng kinh tế tại địa phương và vùng kinh tế trọng điểm phía Nam"33. Nguồn vốn FDI dồi dào cũng góp phần khiến Bình Dương đẩy mạnh phát triển kinh tế và duy trì tốc độ tăng trưởng cao. Thành công này đã chứng minh tính đúng đắn từ nhận định của Thủ tướng Phan Văn Khải "xuất phát từ tỉnh nông nghiệp, chỉ trong vòng mười năm, Bình Dương đã vươn lên thành tỉnh công nghiệp"34.

Sang năm 2008, tỉnh có 127 dự án;nguồn vốn đầu tư FDI thu hút đạt hơn 2 tỉ USD, gấp 2 lần kế hoạch đề ra, với tổng số vốn đăng ký đầu tư là 1.026,1 triệu USD, nâng tổng vốn đầu tư nước ngoài từ trước đến nay lên 11 tỉ USD. Các dự án đầu tư ngày càng được mở rộng từ các đối tác truyền thống là Đài Loan, Hàn Quốc, Nhật Bản cho đến Hà Lan, Phần Lan, Đan Mạch, Mỹ, Anh... ${ }^{35}$.Vào nửa cuối năm 2008, cơn bão khủng hoảng tài chính toàn cầu và vấn đề nợ công của châu Âu đã khiến cho dòng FDI toàn cầu tiếp tục suy giảm đáng kể. Dư chấn từ cuộc khủng hoảng như lạm phát cao, thâm hụt thương mại lớn, thị trường chứng khoán sụt giảm mạnhđã khiến nguồn thu hút FDI vào Việt Nam gặp nhiều thách thức ${ }^{36}$. Trước thực tế đó, năm 2009, Bình Dương vẫn duy trì tốc độ thu hút FDI ổn định với 2, 468 tỉ USD, bằng 2,4 lần kế hoạch năm, trong đó có 99 dự án mới với số vốn 22,2 tỷ USD và 125 lượt dự án

\footnotetext{
32 Phạm Thị Diệu Phúc, "Thu hút nguồn lực từ bên ngoài: Từ thực tiễn của Bình Dương và Quảng Ninh ", Tạp chí Tài chính, 23/5/2014, tại địa chỉ: http://www.tapchitaichinh.vn/Kinh-te-Dau-tu/Thu-hut-nguon-luc-tuben-ngoai-Tu-thuc-tien-cua-Binh-Duong-va-Quang-Ninh/49495.tctc, truy cập ngày 27/2/2015.

33 Lê Anh, "Các tỉnh phía Nam tiếp tục hút mạnh nguồn vốn FDI", Thư viện Tỉnh Bà Rịa - Vũng Tàu, 10/9/2012, tại địa chỉ: http://thuvienbrvt.com.vn/pages/San-pham-thong-tin-ct.aspx?pg=San-pham-thongtin\&par=1\&cat=13\&id=913, truy cập ngày $27 / 2 / 2015$.

${ }^{34}$ Nhiều tác giả (2006), Bình Dương miền đất anh hùng, Nxb. Trẻ, Hội văn học nghệ thuật Bình Dương, tr. 231.

35 "Nguồn vốn FDI "chảy mạnh" vào Bình Dương", VietnamPlus, TTXVN, 30/12/2008, tại địa chỉ: http://www.vietnamplus.vn/nguon-von-fdi-chay-manh-vao-binh-duong/1929.vnp, cập nhật ngày $26 / 2 / 2015$.

${ }^{36}$ Lê Hải Vân, "Đầu tư trực tiếp nước ngoài tại Việt Nam năm 2009 và triển vọng 2010", Tạp chí Cộng sản, 1/3/2010, tại địa chỉ: http://www.tapchicongsan.org.vn/Home/Nghiencuu-Traodoi/2010/33/Dau-tu-tructiep-nuoc-ngoai-tai-Viet-Nam-nam-2009-va.aspx, cập nhật ngày 26/2/2015.
} 
bổ sung vốn 446 triệu USD ${ }^{37}$.Sang năm 2010, Bình Dương có 123 dự án đầu tư FDI với tổng số vốn đăng ký đầu tư là 730,4 triệu USD; với định hướng tiếp tục phát triển theo hướng tăng nhanh về chất và đa dạng về cơ cấu ngành nghề như bất động sản, thương mại dịch vụ, sản xuất phụ tùng xe ô tô, hàng điện tử, thiết bị y tế,...Đáng chú ý là trong nguồn vốn FDI năm 2010 có đến gần $70 \%$ số vốn đầu tư vào các khu công nghiệp. Điều này cho thấy sự chuyển hướng rõ rệt theo chủ trương tập trung đầu tư vào các khu công nghiệphoàn chỉnh có cơ sở hạ tầng tốt, nhằm tạo thuận lợi cho các nhà đầu tư, đồng thời đảm bảo sự phát triển theo hướng bền vững trong thu hút FDI trên địa bàn tỉnh ${ }^{38}$.

Nhìn lại chặng đường hội nhập kinh tế của Bình Dương trong 10 năm đầu thế kỷ XXI, có thể nhận thấy những bước phát triển vượt bậc của Bình Dươngđã tạo tiền đề vững chắc cho những triển vọng trong giai đoạn sau.Cho đến hết năm 2010, công nghiệp Bình Dương thu hút được 1997 dự án FDI, với tổng số vốn đăng ký là 11,08 tỉ USD của hơn 40 quốc gia và vùng lãnh thổ, tương đương 93,5\% số dự án và 80,3\% số vốn FDI đầu tư vào Bình Dương39.

Xét về cơ cấu GDP theo khu vực kinh tế, tỷ phần đóng góp của công nghiệp vào GDP lớn hơn cả tỷ phần của nông nghiệp và dịch vụ cộng lại. Từ 2003 đến 2010, khu vực nông lâm ngư nghiệp (khu vực 1) từ chỗchiếm 11,6\% GDP đã giảm xuống chỉ còn $5,3 \%$. Các ngành dịch vụ (khu vực 3) tăng mức độ đóng góp cho kinh tế của tỉnh từ 26,2\% lên hơn 32,4\%. Công nghiệp (khu vực 2) giữ vị trí chủđạo trong GDP Bình Dương xuyên suốt thời kỳ này và luôn giữ tốc độ bền vững ở mức trên $60 \%$, trong đó nguồn thu từ FDI chiếm phần lớn. Sự ưu tiên cho phát triển công nghiệp là định hướng nhất quán và thể hiện tầm nhìn của Bình Dương nhằm tạo nên lợi thế cạnh tranh chiến lược cho Bình Dương so với những địa phương khác.

\section{Cơ cấu GDP theo khu vực kinh tế của Bình Dương}

Đơn vị tính: \%

\begin{tabular}{|c|c|c|c|c|c|c|c|}
\hline Khu vực & $\mathbf{2 0 0 3}$ & $\mathbf{2 0 0 5}$ & $\mathbf{2 0 0 6}$ & $\mathbf{2 0 0 7}$ & $\mathbf{2 0 0 8}$ & $\mathbf{2 0 0 9}$ & Trung bình \\
\hline Khu vực 1 & 11,60 & 8,40 & 7,00 & 6,40 & 5,70 & 5,30 & 7,40 \\
\hline Khu vực 2 & 62,20 & 63,50 & 64,10 & 64,40 & 64,80 & 62,30 & 63,55 \\
\hline Khu vực 3 & 26,20 & 28,10 & 28,90 & 29,20 & 29,50 & 32,40 & 29,50 \\
\hline
\end{tabular}

Nguồn: Cục Thống kê tỉnh Bình Dương, Niên giám thống kê 2006, 2008, 2009.

37 “Thu hút vốn FDI ở Bình Dương khởi sắc đầu năm”, VietnamPlus, TTXVN, 18/2/2010, tại địa chỉ: http://www.vietnamplus.vn/thu-hut-von-fdi-o-binh-duong-khoi-sac-dau-nam/36265.vnp, truy cập ngày $26 / 2 / 2015$.

38“Thực trạng thu hút vốn đầu tư trực tiếp nước ngoài (FDI) của Vùng Đông Nam Bộ thời gian qua”, Cục Xúc tiến thương mại, 4/2/2012, tại địa chỉ: http://www.vietrade.gov.vn/cac-vung-kinh-t-khac/3590-thc-trngthu-hut-vn-u-t-trc-tip-nc-ngoai-fdi-ca-vung-ong-nam-b-thi-gian-qua-.html, truy cập ngày 28/2/2015.

39 Đỗ Minh Tứ, "Công nghiệp Bình Dương trong quá trình thực hiện đường lối công nghiệp hóa, hiện đại hóa (1997 - 2010)”, tr. 43 trong Nguyễn Văn Hiệp (chủ biên) (2013), Phát triển bền vũ̃ng kinh tế, xã hội tỉnh Bình Dương - Những vấn đề khoa học và thực tiễn, Nxb. Đại học Quốc gia TP. Hồ Chí Minh. 
Xét về tỷ trọng đóng góp của các thành phần kinh tế vào GDP Bình Dương, giai đoạn 20032010 , các doanh nghiệp nhà nước trung bình chỉ đóng góp tầm $20 \%$ vào tổng sản phẩm quốc dân trên địa bàn, trong khi đó khu vực FDI lại luôn chiếm trên dưới 40\%. Năng lực thu hút FDI của Bình Dương là sự phản ánh định hướng thu hút đầu tư nước ngoài để thúc đẩy phát triển kinh tế của tỉnh đã trở thành sự lựa chọn chủ đạo.

Tỷ trọng đóng góp của các thành phần kinh tế vào GDP Bình Dương

Đơn vi tính: \%

\begin{tabular}{|c|c|c|c|c|c|c|c|}
\hline Khu vực kinh tế & $\mathbf{2 0 0 3}$ & $\mathbf{2 0 0 5}$ & $\mathbf{2 0 0 6}$ & $\mathbf{2 0 0 7}$ & $\mathbf{2 0 0 8}$ & $\mathbf{2 0 0 9}$ & Trung bình \\
\hline Khu vực nhà nước & 16,08 & 14,37 & 13,43 & 25,50 & 24,45 & 28,32 & 20,36 \\
\hline Khu vực FDI & 40,68 & 41,58 & 42,23 & 41,70 & 41,49 & 37,81 & 40,91 \\
\hline
\end{tabular}

Nguồn: Cục Thống kê tỉnh Bình Dương, Niên giám thống kê 2006, 2008, 2009; Ủy ban nhân dân tỉnhBình Dương, Báo cáo tình hình kinh tế - xã hội, quốc phòng - an ninh năm 2009.

Những thành tựu mang tính khích lệ này phần lớn là nhờ vào định hướng phát triển đúng đắn của tỉnh. Đại hội Đảng bộ tỉnh Bình Dương lần thứ VII (tháng 1-2001) đề ra mục tiêu chiến lược giai đoạn 2001 - 2010 "chuyển dịch cơ cấu kinh tế theo hướng công nghiệp hóa, hiện đại hóa, tăng dần tỉ trọng công nghiệp và dịch vụ, hội nhập kinh tế với vùng và khu vực; biến tiềm năng thành lợi thế so sánh để thu hút đầu tư"40.Nghị quyết Đại hội Đảng bộ tỉnh lần thứ VIII (tháng 11-2005) tiếp tục đưa ra những phương hướng chỉ đạo thiết thực và đặt mục tiêu cho giai đoạn 2005 - 2010 là "tăng trưởng kinh tế với tốc độ cao và bền vững gắn với văn hóa - xã hội, giữ vững quốc phòng, an ninh"41. Những mục tiêu chiến lược đều tập trung vào kinh tế với ưu tiên hội nhập kinh tế quốc tế song song với phát triển bền vững, chú ý đặc biệt đến văn hóa - xã hội và quốc phòng, an ninh.

Sang thập niên thứ hai của thế kỷ XXI, Bình Dương tiếp tục đẩy mạnh việc thực thi cơ chế "một cửa", tạo sự thông thoáng trong thủ tục hành chính, hệ thống hóa các khu công nghiệp, xây dựng các cơ sở hạ tầng thuận lợi cho làm việc và sinh hoạt, đẩy mạnh quản lý dựa trên hệ thống pháp luật ngày càng rõ ràng, minh bạch với những hướng dẫn cụ thể để tăng cường khả năng thu hút FDI ngày càng hiệu quả. Trong số các tiêu chí hàng đầu đểcác đối tác chọn lựa đầu tư thì hạtầng công nghiệp hoàn chỉnh và hiện đại, có hệthống giao thông thuận lợi và kết nối là những ưu thế cạnh tranh được đánh giá cao ${ }^{42}$. Có thể nói, Bình

\footnotetext{
40Đảng bộ tỉnh Bình Dương (2001), Văn kiện Đại hội đại biểu Đảng bộ tỉnh Bình Dương lần thứ VII, tài liệu lưu hành nội bộ, lưu tại Văn phòng Tỉnh ủy Bình Dương, tr. 36.

41 Đảng bộ tỉnh Bình Dương (2006), Văn kiện Đại hội đại biểu Đảng bộ tỉnh Bình Dương lần thú VIII, tài liệu lưu hành nội bộ, lưu tại Văn phòng Tỉnh ủy Bình Dương, tr. 93.

42 Nguyễn Thị Vân, "Vai trò của đầu tư trực tiếp nước ngoài đối với sự phát triển kinh tế vùng Đông Nam Bộ", Tạp chí Khoa học xã hội, Số 11 (171) - 2012, tr. 21.
} 
Dương ngày càng được xem như điểm đến hấp dẫn của cácnhà đầu tư và được các đối tác nước ngoài lựa chọn là vì sở hữu được những điều kiện thuận lợi này.

Năm 2011, tỉnh Bình Dương đã thu hút thêm 889 triệu USD vốn đầu tư nước ngoài gồm 76 dự án mới với tổng vốn đăng ký 408,5 triệu USD ${ }^{43}$.Năm 2012, dù kinh tế thế giới khu vực và trong nước vẫn chưa vượt qua khủng hoảng, nhưng dòng vốn FDI đổ vào Bình Dương vẫn đứng đầu cả nước, đạt 2,6 tỷ USD/ tổng số gần 10,5 tỷ USD của cả nước, cao hơn thành phố Hồ Chí Minh và Hải Phòng cộng lại, trong đó có 105 dự án đầu tư mới với số vốn đầu tư 1,58 tỷ USD 44 .Báo cáo năng lực hội nhập kinh tế quốc tế cấp địa phương (chỉ số PEII) 2013 do Ủy ban Quốc gia về Hợp tác Kinh tế Quốc tế công bố vào tháng 11/2013, lần đầu tiên thống kê đầy đủ 63 tỉnh, thành cho thấy Bình Dương nằm trong "top 5" dẫn đầu và tiếp tục thể hiện năng lực hội nhập kinh tế quốc tế mạnh mẽ.Căn cứ vào 8 tiêu chí (thương mại, đầu tư, du lịch,con người,văn hóa, cơ sở hạ tầng,đặc điểm địa phương, thể chế), Bình Dương được xếp vào nhóm "Duy trì" với vị trí thứ 3 trên tổng số 63 tỉnh, thành.

Năng lực và tốc độ hội nhập kinh tế quốc tế của Bình Dương còn được đánh giá tích cực trong hội thảo "Năng lực hội nhập kinh tế quốc tế tại tỉnh Bình Dương - tầm nhìn và triển vọng" do Ủy ban Quốc gia về Hợp tác Kinh tế Quốc tế phối hợp với tỉnh Bình Dương tổ chức ngày 16-12-2013.Với chính sách lành mạnh, quan tâm hỗ trợ doanh nghiệp về các thủ tục hành chính, tạo điều kiện cho doanh nghiệp nhanh chóng tiếp cận các nguồn vốn đầu tư phát triển sản xuất kinh doanh, đổi mới công nghệ sản xuất,... Bình Dương là một trong những tỉnh, thành có bước phát triển nhanh và mạnh trong hội nhập kinh tế quốc tế45.Trong năm 2013, quá trình thu hút FDI của Bình Dương đã gia tăng mạnh trên 1,3 tỷ USD, chiếm gần $10 \%$ cả nước. Kết quả đầy khả quan này đã góp phần thể hiện rõ tính hiệu quả của Bình Dương trong việc chủ động hội nhập trong các thành phần kinh tế, nâng tổng số dự án trên địa bàn tỉnh hiện còn hiệu lực 17.259 doanh nghiệp trong và ngoài nước với số vốn lên đến 18,5 tỷ USD và gần 120.000 tỷ đồng. Năm 2014, Bình Dương đã thu hút lượng vốn FDI hơn 1,6 tỷ USDvới 151 dự án đầu tư mới. Nguồn vốn FDI này đã vượt hơn $65 \%$ so với kế hoạch đề ra và tăng $23 \%$ so với cùng kỳ năm trước. Kết quả đầy tính khích lệ này đã giúp Bình Dương đứng vị trí thứ 3 cả nước, sau Thái Nguyên và thành phố Hồ Chí Minh46.

\footnotetext{
${ }^{43}$ Quách Lắm, "Tín hiệu vui về thu hút vốn FDI ở tỉnh Bình Dương”, VietnamPlus, TTXVN, 8/12/2011, tại địa chỉ: http://www.vietnamplus.vn/tin-hieu-vui-ve-thu-hut-von-fdi-o-tinh-binh-duong/119197.vnp, truy cập ngày $26 / 2 / 2015$.

44 "Hiệu quả từ thu hút, sử dụng vốn FDI ở Bình Dương”, Ban Quản lý các khu công nghiệp Bình Dương , $1 / 7 / 2013$,

http://kcn.binhduong.gov.vn/bantin/pages/CMSDetail.aspx?TabID=1\&MenuID=1\&ArticleID=ARTICLE12120 $\underline{005}$, truy cập ngày $26 / 2 / 2015$.

45 Dương Chí Tưởng, "Bình Dương là một trong những tỉnh hội nhập kinh tế nhanh nhất", Báo Hải quan, 17/12/2013, tại địa chỉ: http://www.baohaiquan.vn/pages/binh-duong-la-mot-trong-nhung-tinh-hoi-nhapkinh-te-nhanh-nhat-ca-nuoc.aspx, truy cập ngày 26/2/2015.

46 Hồng Sơn, "Bình Dương thu hút 1,6 tỷ USD vốn FDI, lọt Top 3 cả nước", Báo đầu tư, 17/12/2014, tại địa chỉ: http://baodautu.vn/binh-duong-thu-hut-16-ty-usd-von-fdi-lot-top-3-ca-nuoc.html, truy cập ngày 26/2/2015.
} 
Hiện nay Bình Dương còn được đặc trưng bởi tốc độ phát triển nhanh chóng của các khu công nghiệp. Bình Dương là một trong những địa phương đi tiên phong trong việc vận dụng hình thức "tô nhượng" thông qua hình thành các khu công nghiệp tập trung; trong đó khu công nghiệp Bình Đường, Sóng Thần I hình thành từ năm 1993 là những khu công nghiệp đầu tiên trong cả nước ${ }^{47}$.Thành công của Sóng Thần I đã tạo điều kiện để Bình Dương có khu công nghiệp Việt Nam - Singapore (VSIP) ${ }^{48}$, quy mô 500ha với sự liên doanh giữa Việt Nam và Singapore. Cho đến nay, VSIP đã trở thành là khu công nghiệp kiểu mẫu và là mũi nhọn trong xu thế hội nhập kinh tế quốc tế của Bình Dương ${ }^{49}$. Nhìn chung, sự phát triển của các khu công nghiệp đã trở thành các "thỏi nam châm" góp phần thu hút lượng dồi dào FDI để thúc đẩy các hoạt động sản xuất, thu hút việc làm và nâng cao hình ảnh của một tỉnh phát triển năng động và đầy tiềm năng ở phía Nam.Với lợi thế là điểm đến năng động, luôn nhạy bén trước những vận hội mới, Bình Dương đã dần trở thành điểm đến tin cậy và là ưu tiên của nhiều doanh nghiệp có vốn đầu tư nước ngoài. Theo Ban quản lý Khu công nghiệp Bình Dương, các doanh nghiệp/ dự án có vốn đầu tư nước ngoài tại Bình Dương (cập nhật đến 10/4/2014) đã nâng lên đến con số $911^{50}$.

Có thể kể ra các khu công nghiệp tiêu biểu như khu kỹ nghệ Singapore, khu công nghiệp Phú Gia (huyện Bến Cát);khu công nghiệp VSIP 1, 2A, 2B, Bình Chuẩn, Đông An(huyện Thuận An);khu công nghiệp Tân Đông Hiệp A, Tân Hiệp B, Tân Đông Hiệp, Tân Bình (huyện Dĩ An);khu công nghiệp Nam Tân Uyên (huyện Tân Uyên);khu công nghiệp Mỹ Phước 3 (thị xã Bến Cát); khu công nghiệp Tân Định An,cụm công nghiệp Phú Hòa, cụm công nghiệp An Phú (thị xã Thủ Dầu Một),... Những khu công nghiệp này đã gia tăng lợi thế cạnh tranh của Bình Dương, mang lại cho Bình Dương một diện mạo kinh tế hoàn toàn mớimẻ so với các tỉnh, thành phía nam còn lại.

\footnotetext{
47 Nguyễn Văn Hiệp (2013), Sự chuyển biến kinh tế - xã hội tỉnh Bình Dương 1945 - 2007, Sđd, tr. 233.

48 Ban Quản lý khu công nghiệp VSIP được thành lập theo Quyết định số 870/QĐ-TTg ngày 18-11-1996 của Thủ tướng Chính phủ Việt Nam. Đến tháng 12-2000, VSIP đã nhận được chứng chỉ quản lý chất lượng ISO 9001-2000. Đến năm 2007, VSIP là một trong 40 thương hiệu đạt “Saigon Times top 40 năm 2007", đồng thời là một trong số 20 công trình kiến trúc tiêu biểu của Việt Nam thời kỳ đổi mới. "Công ty liên doanh trách nhiệm hữu hạn Khu công nghiệp Việt Nam - Singapore", tr. 399-403 trong Công ty Cổ phần Thông tin Đối ngoại (2008), Bình Dương hội nhập - Bài học thành công, Sđd.

49 “Tạo sức bật trong thời kỳ hội nhập", tr. 12 trong Công ty Cổ phần Thông tin Đối ngoại (2008), Bình Dương hội nhập - Bài học thành công, Sđd.

${ }^{50}$ Trong đó, theo các con số tác giả thống kê thì số doanh nghiệp/ dự án nước ngoài tại khu công nghiệp An Tây là 16, khu công nghiệp Bàu Bàng là 33, khu công nghiệp Bình An là 2, khu công nghiệp Bình Đường là 10, khu công nghiệp Đại Đăng là 42, khu công nghiệp Đất Cuốc là 24, khu công nghiệp Đồng An là 101, khu công nghiệp Đồng An 2 là 17, khu công nghiệp Kim Huy là 14, khu công nghiệp Mai Trung là 3, khu công nghiệp Mỹ Phước là 47, khu công nghiệp Mỹ Phước 2 là 90, khu công nghiệp Mỹ Phước 3 là 147, khu công nghiệp Nam Tân Uyên 62, khu công nghiệp Phú Gia là 1, khu công nghiệp Rạch Bắp là 2, khu công nghiệp Sóng Thần 1 là 76 , khu công nghiệp Sóng Thần 2 là 89 , khu công nghiệp Sóng Thần 3 là 25 , khu công nghiệp Tân Đông Hiệp $\mathrm{A}$ là 6, khu công nghiệp Tân Đông Hiệp B là 7, khu công nghiệp Việt Hương là 57, khu công nghiệp Việt Hương là 2 là 39, khu công nghiệp Nam Kim là 1 . Danh sách các doanh nghiệp có vốn đầu tư nước ngoài trong các khu công nghiệp (cập nhật đến ngày 10/04/2014), Ban quản lý khu công nghiệp Bình Dương, tại địa chỉ:http://kcn.binhduong.gov.vn/bantin/pages/CMSDetail.aspx?tabid=4\&MenuID=4\&ArticleID=ARTICLE110 50005\%20\&MenuID=4, cập nhật ngày 26/2/2015.
} 
Với chính sách "trải thảm đỏ, đón nhà đầu tư" để thu hút các nhà đầu tư nước ngoài, Bình Dương đã nhanh chóng bắt nhịp với xu thế hội nhập kinh tế quốc tế năng động và hiệu quả từ thành phố Hồ Chí Minh. Việc tích cực học hỏi và trao đổi kinh nghiệm từ những mô hình hội nhập kinh tế quốc tế của các khu công nghiệp trên địa bàn thành phố Hồ Chí Minh vừa giúp Bình Dương tiếp thu những bài học kinh nghiệm quý giá, vừa tự đổi mới chính mình để phát triển.Cùng với điểm cầu kinh tế phía Nam là thành phố Hồ Chí Minh thì Bình Dương đã đóng góp tích cực vào nâng cao chất lượng hội nhập kinh tế phía Nam để tạo nên một khu vực phát triển năng động của đất nước.

Cho đến giữa thập niên thứ hai của thế kỷ XXI, Bình Dương đã tạo được nhiều bước chuyển biến để hỗ trợ cho công cuộc hội nhập kinh tế quốc tế. Được khởi công xây dựng từ tháng $11 / 2010$ và chính thức khánh thành vào tháng $2 / 2014$, thành phố mới Bình Dương với quy mô 1.000 ha nằm trong Khu liên hợp Công nghiệp - Đô thị - Dịch vụ có diện tích gần 4.200 ha, sẽ trở thành một thành phố "khoa học, công nghệ và tri thức", là cửa ngõ thu hút nguồn lực mới cho quá trình phát triển công nghệ cao và các dịch vụ tài chính - ngân hàng thương mại quốc tế; là nơi đủ khả năng kiến tạo quá trình ươm mầm các doanh nghiệp mới ${ }^{51}$. Nhận định sức phát triển không ngừng của Bình Dương, nhiều tập đoàn nước ngoài như Khu công nghệ của Tập đoàn Mapletree (Singapore), Tập đoàn Tokyu (Nhật Bản),... đã đến hợp tác và đầu tư tại trung tâm Thành phố mới Bình Dương.

\section{Kết luận}

Trong tổng thể bức tranh hội nhập kinh tế quốc tế phía Nam, Bình Dương là một dấu ấn đặc biệt không thể nhầm lẫn.Kể từ năm 1986, Bình Dương đã hòa vào xu thế lấy kinh tế là trọng điểm và tích cực hội nhập kinh tế quốc tế để "xây dựng, phát triển và hội nhập". Gần 30 năm (1986 - 2015) với nhiều thăng trầm trong nỗ lực tự khẳng định mình, sau thành phố Hồ Chí Minh thì Bình Dương đã trở thành “điểm nhận diện"quan trọng thứ hai về hội nhập kinh tế quốc tế ở miền Đông Nam Bộ. Những thành tựu từ công cuộc hội nhập kinh tế quốc tế của Bình Dương không chỉ đóng góp to lớn vào sự phát triển kinh tế và chất lượng nguồn nhân lực phía Nam mà còn cùng với thành phố Hồ Chí Minh góp phần định hướng Việt Nam là một môi trường kinh tế giàu tiềm năng và triển vọng phát triển.Đặc biệt, từ đầu thế kỷ XXI đến nay Bình Dương luôn chứng tỏ tính bền vững trong quá trình thu hút nguồn vốn FDI và giữ vững vị trí trong "top 10".Nếu như thành phố Hồ Chí Minh chứng tỏ thế mạnh ở các khu chế xuất thì Bình Dương lại chiếm ưu thế về các khu công nghiệp. Sự chủ động định vị hình ảnh phát triển này của Bình Dương đã chứng tỏ tính hiệu quả khi các khu công nghiệp của tỉnh đã thu hút một số lượng vốn đầu tư nước ngoài đáng kể.

Hiện nay, hội nhập kinh tế quốc tế theo hướng bền vững với việc cân nhắc những tác động từ môi trường, con người và điều kiện sinh hoạt là rất quan trọng. Để củng cố cho hoạt động

51 "Bình Dương chuyển mình, vươn tầm cao mới”, Becamex IDC Corp, 25/2/2014, tại địa chỉ: http://becamex.com.vn/vn/tin-tuc-su-kien/thong-tin-do-thi-an-sinh-xa-hoi/thong-tin-do-thi-an-sinh-xahoi/binh-dng-chuyn-minh-vn-tm-cao-mi, truy cập ngày $27 / 2 / 2014$. 
thu hút FDI thì những vấn đề như cân bằng cơ cấu ngành nghề, việc bảo tồn các đặc trưng văn hóa, sự ổn định về tình hình chính trị - xã hội, bảo vệ môi trường, tinh thần ham học hỏi và giàu tính sáng tạo của người lao động,... cũng là những yếu tố góp phần tạo nên một hình ảnh Bình Dương mến khách và hiền hòa trong mắt các nhà đầu tư nước ngoài. Từ góc độ lý luận và thực tiễn, có thể nhận thấy rằng "trong quá trình phát triển của một tỉnh hay một quốc gia điểm bất lợi có thể trở thành lợi thế, và điểm lợi thế ban đầu có thể trở thành bất lợi tùy thuộc vào sự năng động của từng địa phương”52. Việc phát triển có định hướng, đồng bộ các chính sách, tận dụng ưu thế con người (cần cù, năng động, chịu khó,...) và sức trẻ của địa phương, khai thác tối đa thế mạnh của các khu công nghiệp,... đểhội nhập kinh tế quốc tế là những yếu tố quan trọng giúp nâng cao sức hấp dẫn của Bình Dương trong thời đại toàn cầu hóa và hội nhập quốc tế.

Trong thời gian tới, để tăng cường chất lượng và đẩy nhanh tốc độ hội nhập kinh tế quốc tế của Bình Dương, cần chú trọng vào những biện pháp: (i) mang tính “đồng bộ"với định hướng lâu dài và đẩy mạnh phát triển các lĩnh vực khoa học -công nghệ vốn đang rất cần cho sự phát triển của Bình Dương; (ii) mang tính "bền vững"-phát triển đi đôi với tôn tạo và bảo vệ nguồn tài nguyên thiên nhiên, môi trường, nguồn nước,... đặc biệt phải lưu tâm đến nguồn lợi cho các thế hệ sau phát huy và sử dụng; (iii) lưu tâm đến "nhân tố con người"-đối tượng trực tiếp làm nên chất lượng hội nhập kinh tế quốc tế, thông qua đào tạo nguồn nhân lực "vừa hồng, vừa chuyên"; (iv) tăng cường "sự ủng hộ và niềm tin của người dân" đối với những quyết sách của chính quyền, doanh nghiệp. Trên hết, Bình Dương cần hướng đến việc "tiếp tục tạo môi trường đầu tư thuận lợi, an toàn và tin cậy cho doanh nghiệp cả trong và ngoài nước. Chú ý lựa chọn các nhà đầu tư có công nghệ, hàm lượng khoa học - kỹ thuật, giá trị gia tăng cao, đạt các tiêu chuẩn về bảo vệ môi trường sinh thái và nằm trong chuỗi giá trị gia tăng toàn cầu" 53 .

Những thành tựu đã đạt được của Bình Dương từ công cuộc hội nhập kinh tế quốc tế trong thời gian qua xuất phát từ những nỗ lực bên trong và việc tranh thủ các nguồn lực cùng sự ủng hộ quốc tế đã tạo nên lợi thế cạnh tranh của địa phương so với các tỉnh, thành khác trong cả nước. Trong mối tương quan với các đô thị trong khu vực, Bình Dương cũng tạo được nhiều dấu ấn độc đáo và hiện đang trong quá trình tự làm mới mìnhqua việc thiết lập nhiều mối giao lưu tích cực để tăng cường tính tương tác hiệu quả với nền kinh tế khu vực. Trong bối cảnh hội nhập kinh tế quốc tế ngày càng có mối quan hệ chặt chẽ với các lĩnh vực hội nhập quốc tế khác (chính trị, an ninh - quốc phòng, khoa học - công nghệ, văn hóa - xã hội,...) thì Bình Dương cần cân nhắc để có sự phối hợp đồng bộ và bền vững giữa các hoạt động kinh tế với chính trị, văn hóa - xã hội,... Với sự phát triển năng động trong thời gian

\footnotetext{
52 Trần Thị Hằng, "Yếu tố quan trọng giúp nâng cao năng lực cạnh tranh của Bình Dương",Trung tâm nghiên cứu kinh tế miền Nam, phiên bản điện tử có tại địa chỉ: http://svec.org.vn/uploads/nghiencuu/2014_02/binhduong-canhtranh-hang.pdf, truy cập ngày 28/2/2015.

53 "Xây dựng Bình Dương trở thành thành phố công nghiệp tiêu biểu", tr. 125 trong Thư viện tỉnh Bình Dương (2010), Thư mục toàn văn Bình Dương hội nhập và phát triển, Nxb. Trẻ.
} 
qua cùng sự quan tâm và định hướng đúng đắn của lãnh đạo tỉnh, Bình Dương có nhiều tiềm năng và điều kiện tiếp tục hội nhập vào nền kinh tế thế giới để mang lại nhiều lợi thế cạnh tranh cho vùng đất mới. 


\section{Tài liệu tham khảo}

1. Đảng bộ tỉnh Bình Dương (2001), Văn kiện Đại hội đại biểu Đảng bộ tỉnh Bình Duơng lần thư VII, tài liệu lưu hành nội bộ, lưu tại Văn phòng Tỉnh ủy Bình Dương.

2. Đảng bộ tỉnh Bình Dương (2006), Văn kiện Đại hội đại biểu Đảng bộ tỉnh Bình Duoong lần thứ VIII, tài liệu lưu hành nội bộ, lưu tại Văn phòng Tỉnh ủy Bình Dương.

3. Đảng Cộng sản Việt Nam (2008), Văn kiện Đại hội Đảng thời kỳ đổi mới và hội nhập, Nxb. Chính trị Quốc gia, Hà Nội.

4. Công ty Cổ phần Thông tin Đối ngoại (2008), Bình Dương hội nhập - Bài học thành công, Nxb. Chính trị Quốc gia, Hà Nội.

5. Hồ Sơn Đài (chủ biên) (2010), Lịch sủ Lực lương Vũ trang Nhân dân tỉnh Bình Dương (1945 - 2005), Nxb. Tổng hợp thành phố Hồ Chí Minh.

6. Nguyễn Khắc Huỳnh (2011), Ngoại giao Việt Nam - Góc nhìn và suy ngẫm, Nxb. Chính trị quốc gia, Hà Nội.

7. Nguyễn Văn Hiệp (chủ biên) (2013), Phát triển bền vũng kinh tế, xã hội tỉnh Bình Dưong Những vấn đề khoa học và thực tiễn, Nxb. Đại học Quốc gia TP. Hồ Chí Minh.

8. Nguyễn Văn Hiệp (2013), Sụ chuyển biến kinh tế - xã họi tỉnh Bình Duơng 1945 - 2007, Nxb. Chính trị Quốc gia, Hà Nội.

9. Nguyễn Xuân Oánh (2001), Đổi mới - Vài nét lớn của một chính sách kinh tế Việt Nam, Nxb. Thành phố Hồ Chí Minh.

10. Nguyễn Xuân Thắng (chủ biên) (2007), Toàn cầu hóa kinh tế và hội nhập kinh tế quốc tế đối với tiến trình công nghiệp hóa, hiện đại hóa ở Việt Nam, Nxb. Khoa học xã hội, Hà Nội.

11. Nhiều tác giả. (2006), Bình Dưong miền đất anh hùng, Nxb. Trẻ,Hội Văn học nghệ thuật Bình Dương.

12. Phạm Bình Minh (chủ biên) (2011), Định hướng chiến lược đối ngoại Việt Nam đến 2020, Nxb. Chính trị Quốc gia, Hà Nội.

13. Phạm Minh Chính, Vương Quân Hoàng. (2009). Kinh tế Việt Nam: Thăng trầm và đột phá. Nxb. Chính trị Quốc gia, Hà Nội.

14. Thư viện tỉnh Bình Dương (2010), Thu mục toàn văn Bình Dương hội nhập và phát triển, Nxb. Trẻ.

15. Võ Văn Sen (chủ biên) (2013), Nam Bộ - Đất và Người (Tập IX), Nxb. Đại học Quốc gia thành phố Hồ Chí Minh. 